Article

\title{
Respiratory Syncytial Virus Persistence in Macrophages Upregulates Fcgamma Receptors Expression
}

\author{
Jorge Gaona ${ }^{1}$, Carlos Santiago-Olivares ${ }^{1}$, Enrique Ortega ${ }^{2}$ and Beatriz Gómez ${ }^{1, *}$ \\ 1 Department of Microbiology and Parasitology, Faculty of Medicine, National Autonomous \\ University of Mexico (UNAM), Ciudad Universitaria, D.F. Mexico C.P. 04510, Mexico; \\ E-Mails: jgaber2007@gmail.com (J.G.); carlosantiagolivares@yahoo.com.mx (C.S.-O.) \\ 2 Department of Immunology, Biomedical Research Institute, National Autonomous University of \\ Mexico (UNAM), Ciudad Universitaria, D.F. México C.P. 04510, Mexico; \\ E-Mail: ortsoto@unam.mx \\ * Author to whom correspondence should be addressed; E-Mail: begomez@unam.mx; \\ Tel.: +52-55-5623-2469; Fax: +52-55-5623-2382.
}

Received: 14 October 2013; in revised form: 29 November 2013 / Accepted: 15 January 2014 / Published: 6 February 2014

\begin{abstract}
Viruses can persist in differentiated cells (i.e., macrophages) over long periods of time, altering host cells functions but not inducing their death. We had previously reported that, in early passages (14-40) of a murine macrophage-like cell line persistently infected with respiratory syncytial virus (RSV) $(\mathrm{M} \phi \mathrm{P}), \mathrm{Fc} \gamma \mathrm{R}$-mediated phagocytosis and expression of FcyRIIB/RIII on the cell membrane were increased with respect to mock-infected macrophages $(\mathrm{M} \phi \mathrm{N})$. In this work, we explored the mechanism underlying such effects. Increases in FcyR expression and Fc $\gamma \mathrm{R}$-mediated phagocytosis are preserved after more than 87 passages of the persistently infected culture. We analyzed the expression of Fc $\gamma \mathrm{R}$ isoforms at both mRNA and protein levels, and found out that RSV persistence distinctly affects the expression of FcyR isoforms. We also observed that the increase in Fc $\gamma \mathrm{Rs}$ expression results neither from soluble factors (cytokines) or viral products released by the infected cells, nor from an increase in the rate of $F c \gamma R$ internalization. Our results suggest that RSV persistence in macrophages induce intracellular effects that have an impact on Fc $\gamma$ Rs gene expression at both mRNA and protein levels, and that the characteristics of RSV persistence were preserved for over 87 passages.
\end{abstract}

Keywords: RSV persistence; macrophages; FcyRs expression 


\section{Introduction}

Viruses persisting in differentiated cells-i.e., macrophages $(\mathrm{M} \phi \mathrm{s})$ - can regulate the expression of both their own genes and those of the host cell in order to achieve residence in a non-lytic state, besides selectively affecting functions of the infected cell without destroying it [1]. M $\phi$ s play very important roles in innate and adaptive immune responses since they are involved in various processes, such as phagocytosis, antigen presentation, and cytokine production [2,3]. Mфs express on their membrane receptors for the Fc region of IgG antibodies (Fc $\gamma \mathrm{Rs}$ ). Alterations of Fc $\gamma \mathrm{Rs}-$ mediated phagocytosis in vitro and in vivo have been reported in M $\phi$ s persistently infected with an RNA virus (HIV-1). This effect is caused by a decreased synthesis of the gamma chain of receptors, suggesting that viral persistence alters gene expression in the host cell [4,5]. Changes in host cell-gene expression resulting from persistence of respiratory syncytial virus (RSV), another RNA virus, have also been reported: in the human epithelial cell line HEp-2, viral persistence alters the expression of host genes involved in cell survival and chemokine production [6]. Also, we had previously shown that, in a

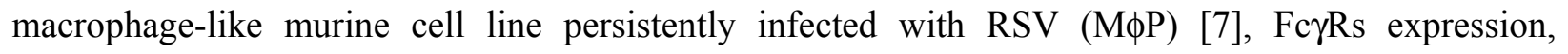
FcyRs-mediated phagocytosis, and cytokines production are altered [8].

Cell-surface FcyRs comprise a family of integral membrane glycoproteins expressed by most leukocytes. Murine M $\phi s$ express four different Fc $\gamma R s$ : while Fc $\gamma$ RI, Fc $\gamma R I I I$, and Fc $\gamma R I V$ are activatory, Fc $\gamma R$ IIB

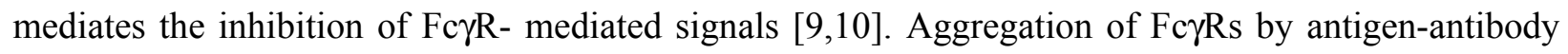
complexes or IgG-opsonized particles triggers several effects or functions, including phagocytosis [11]. FcyRs have also been shown to participate in both the afferent phase of immune responses and immune system homeostasis [12,13].

RSV, a paramyxovirus of the genus Pneumovirus, is prevalent and highly infectious [14]. Worldwide, it is a very important pathogen that causes frequent acute upper and lower respiratory tract infections, especially among infants and young children $[15,16]$. RSV is also a paramount cause of morbidity and mortality in the elderly and in immunocompromised patients [17], constituting the second leading cause of death due to viral infections in elderly individuals [18]. While seasonal RSV outbreaks occur each year globally, the RSV virus can be detected only during the winter epidemic season $[14,19]$. Young children who have recovered from severe RSV bronchiolitis often develop chronic and recurrent respiratory problems [20,21]. The link between RSV infection, the development of sequelae (wheezing, asthma) [22,23] and chronic obstructive pulmonary disease has been clearly established in several well-controlled prospective epidemiological studies [24,25], suggesting that RSV persists in individuals with this condition [26]. The delayed effects of severe RSV disease might be partially explained by viral persistence, which may cause chronic inflammation [26,27] and/or change cell genome expression patterns.

Persistent infection with RSV occurs in patients with T-cell immunodeficiencies, and establishing persistent infections in tissue culture of either epithelial or hematopoietic cells (e.g., HEp-2 [6] or Mф [7]) is easy. RSV persistence in animal models has been reported in infected nude mice [28-30], which develop chronic airway function abnormalities [31-33]. Persistence of bovine respiratory syncytial virus, which is closely related to RSV, has also been demonstrated in B cells from naturally infected cows [34]. Although viral persistence in humans has not been clearly proven, circumstantial evidence suggests its occurrence. Immunohistological observations indicate the presence of RSV antigens in 
osteoclasts and in multinucleated cells formed in bone marrow cultures from patients with Paget's disease [35]. In addition, RSV nucleic acid was detected in archival postmortem lung tissue from infants who had died during the summertime, without apparent clinical disease having been reported, suggesting that the virus might persist in lungs after an acute infection [36]. Since no animal reservoir of RSV has been found, persistent human infections by RSV may be implicated, at least partially, in preserving the virus during inter-epidemic periods. Despite the evidence that RSV is able to establish persistent infections in various cell types, and the possible relationship between RSV persistence and human disease [23-26,37], few studies have investigated the effects that persistent infection by this virus can have on the functions of infected cells.

We have previously reported that persistent infection by RSV in a murine macrophage-like cell line

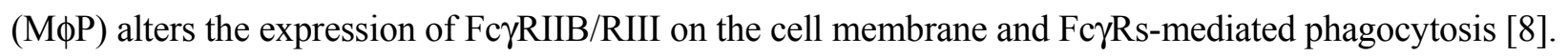
In this work, we explored the mechanism underlying such effects, studying the effect of RSV persistence on the expression of the different Fc $\gamma \mathrm{R}$ isoforms at both mRNA and protein level, and determining whether the effect is caused by soluble factors (cytokines) or viral products released by infected cells.

\section{Results and Discussion}

\subsection{Results}

\subsubsection{Persistent Infection by RSV Increases Fc $\gamma R$-mediated Phagocytosis and FcyRIIB/RIII} Expression even at High Passage Numbers

Throughout this paper, we refer to $\mathrm{M} \phi \mathrm{P}$ as cells of the murine macrophage-like cell line (P388D1) persistently infected with RSV, and to M $\phi \mathrm{N}$ as mock-infected P388D1 cells. Persistent infection in the $\mathrm{M} \phi \mathrm{P}$ cultures used in these experiments was confirmed by the presence of mRNA for the $\mathrm{N}$ gene and the expression of viral antigens in $92 \%-96 \%$ of cells (Figure 1). Viral persistence parameters (infective units in culture supernatants and \% of RSV antigen-positive cells) did not differ significantly from earlier reported values [7].

Previously, we had reported that in $\mathrm{M} \phi \mathrm{P}$ early passages (14-40), Fc $\gamma$ Rs-mediated phagocytosis and plasma membrane expression of Fc $\gamma \mathrm{RIIB} / \mathrm{RIII}$ increase in comparison with non-infected $\mathrm{M} \phi \mathrm{N}$ [8]. In this work, we evaluated whether the same characteristics were present in $\mathrm{M} \phi \mathrm{P}$ later culture passages (72 to 87). Phagocytosis and expression of Fc $\gamma$ RIIB/RIII were determined as previously described [8]. We found out that, after more than 70-80 passages, M $\phi \mathrm{P}$ still showed higher levels of phagocytic activity and cell surface Fc $\gamma$ RIIB/RIII expression than M $\phi \mathrm{N}$ cells (Figure 2). As expected, phagocytic activity was dependent on the IgG concentration used for opsonization, and the phagocytosis of IgG-opsonized sheep red blood cells (SRBCs) by M $\phi \mathrm{P}$ was always significantly higher (usually by a factor of 2) than that of $M \phi N$. It is noteworthy that no differences were observed in the phagocytosis of non-opsonized erythrocytes, which suggests that the effect is characteristic of FcyR-mediated phagocytosis (Figure 2A). Increases in the expression of cell surface Fc $\gamma$ RIIB/RIII in M $\phi \mathrm{P}(50 \%-72 \%)$ (Figure 2B) was similar to those previously reported for early culture passages [8]. 
Figure 1. RSV persistence in $\mathrm{M} \phi \mathrm{P}$. (A) Presence of mRNA of the $\mathrm{N}$ gene in $\mathrm{M} \phi \mathrm{P}$. Agarose/EtBr gel (2\%) electrophoresis of RT-PCR products. Total RNA from three different passages of $\mathrm{M} \phi \mathrm{P}(72,83$ and 87$)$ or $\mathrm{M} \phi \mathrm{N}$ cells was harvested and converted to cDNA. DNA primers for the $\mathrm{N}$ gene were used to amplify a segment of $1,187 \mathrm{bp}$ by PCR. As control, a segment of RNA for GAPDH was amplified; (B) Expression of RSV antigens on M $\phi P$ membrane. $\mathrm{M} \phi \mathrm{N}$ (empty histogram) or $\mathrm{M} \phi \mathrm{P}$ (gray histogram) were stained with FITC-labeled anti RSV antibodies and analyzed by flow cytometry. Histogram is representative of several experiments with different passages of $\mathrm{M} \phi \mathrm{P}$ and $\mathrm{M} \phi \mathrm{N}$ during the course of these experiments.

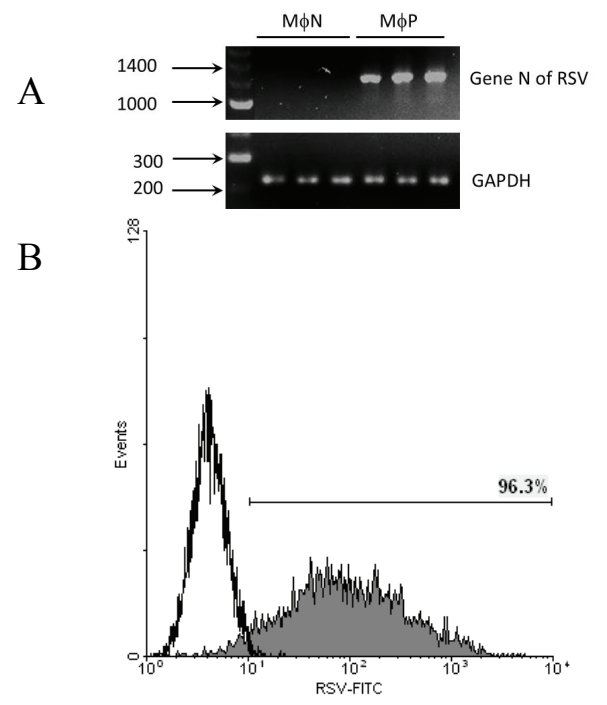

Figure 2. FcyRIIB/RIII mediated phagocytic activity and expression of FcyRIIB/RIII receptors in $\mathrm{M} \phi \mathrm{P}$ and $\mathrm{M} \phi \mathrm{N}$. (A) Phagocytosis of IgG-opsonized and non-opsonized SRBC by $\mathrm{M} \phi \mathrm{N}$ and $\mathrm{M} \phi \mathrm{P}$. Cells were incubated with 2,4,6-trinitrophenyl-labeled SRBC opsonized with the indicated concentrations of the anti-2,4-dinitrophenol (anti-DNP) IgG antibody $4 \mathrm{~F} 8$. Results are expressed as mean \pm 1 SD from three independent experiments passages of $\mathrm{M} \phi \mathrm{N}$ and passages 72, 83 and 87 of $\mathrm{M} \phi \mathrm{P}(* p<0.05)$; (B) Expression of Fc $\gamma \mathrm{RIIB} / \mathrm{RIII}$ in the above mentioned passages of $\mathrm{M} \phi \mathrm{N}$ or $\mathrm{M} \phi \mathrm{P}$ cells. Cell-membrane Fc $\gamma \mathrm{RIIB} / \mathrm{RIII}$ were stained with specific monoclonal antibody $2.4 \mathrm{G} 2$ and secondary FITC-labeled F(ab') fragments of anti-rat antibodies, and analyzed by flow cytometry. Each individual bar represents the MFI of 10,000 cells. Statistical analysis of the average of the three different passages of $\mathrm{M} \phi \mathrm{N}$ and $\mathrm{M} \phi \mathrm{P}(38.67 \pm 2.4 v s .60 .33 \pm 4.9$, respectively) indicates a significant difference in Fc $\gamma$ RIIB/RIII expression $(p=0.016)$.
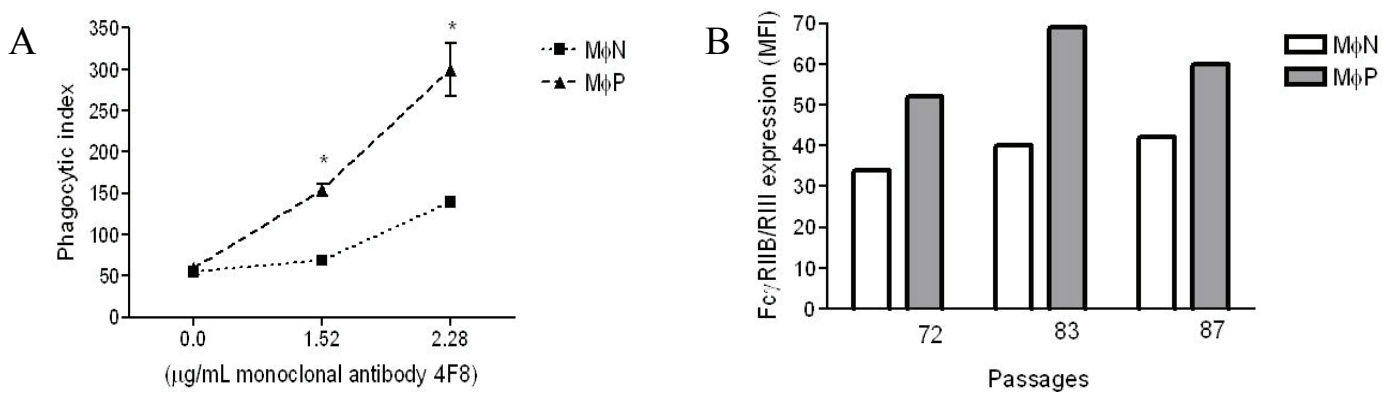


\subsubsection{Increase in FcyRIIB/RIII Cell Membrane Expression Is Not Mediated by Soluble Factors}

Persistence of RSV in macrophages could induce the release of extracellular factors (e.g., cytokines, viral particles, viral products), which would act in a paracrine-like way in order to induce the increase

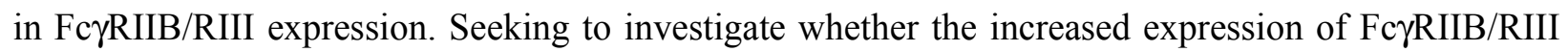
was produced by factors released by persistently infected $\mathrm{M} \phi \mathrm{P}$, we treated $\mathrm{M} \phi \mathrm{N}$ cells with a conditioned medium obtained from $\mathrm{M} \phi \mathrm{N}$ or $\mathrm{M} \phi \mathrm{P}$ cultures after an incubation period of $12 \mathrm{~h}$ or $24 \mathrm{~h}$. Expression levels of FcyRIIB/RIII were determined by flow cytometry. Mean fluorescence intensity (MFI) of Fc $\gamma$ RIIB/RIII expression by $\mathrm{M} \phi \mathrm{N}$ was not significantly altered when $\mathrm{M} \phi \mathrm{N}$ were incubated for $24 \mathrm{~h}$ with supernatants from $\mathrm{M} \phi \mathrm{N}$ or $\mathrm{M} \phi \mathrm{P}$ (Figure 3). So as to verify that $\mathrm{M} \phi \mathrm{N}$ are able to increase the expression of Fc $\gamma$ RIIB/III in response to a stimulus already known to increase the expression of these receptors [38], M $\phi \mathrm{N}$ were incubated with heat-killed NHTi, which induced a significant increase in FcyR expression as compared to cells treated with conditioned medium (Figure 3). This suggests that the $\mathrm{M} \phi \mathrm{N}$ cell line is able to respond to an activating stimulus. These results show that the increase in the expression of FcyRIIB/III induced by RSV persistence is not mediated by extracellular factors released by persistently infected cells.

Figure 3. Fc $\gamma R$ RIB/RIII expression in $\mathrm{M} \phi \mathrm{N}$ after treatment with $\mathrm{M} \phi \mathrm{N}$ or $\mathrm{M} \phi \mathrm{P}$ conditioned medium (CM). M $\phi \mathrm{N}$ were treated with either $12 \mathrm{~h}$ - or $24 \mathrm{~h}-\mathrm{CM}$ from $\mathrm{M} \phi \mathrm{N}$ or $\mathrm{M} \phi \mathrm{P}$, or with heat-killed NTHi as control (see Materials and Methods for details). After $24 \mathrm{~h}$, FcyRIIB/RIII was analyzed by flow cytometry. Results are expressed as mean $\pm 1 \mathrm{SD}$ of mean fluorescence intensity in three independent experiments.

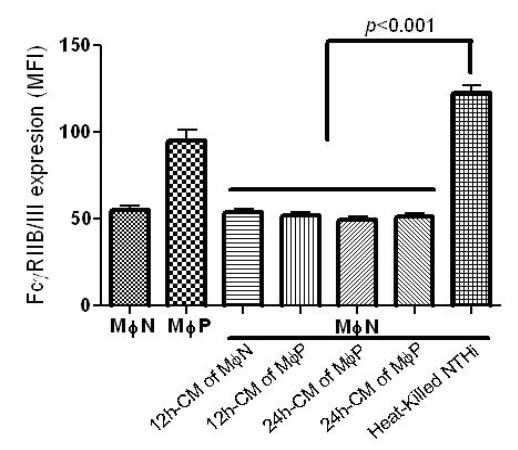

\subsubsection{RSV Persistence does not Affect Fc $\gamma$ RIIB/RIII Endocytosis}

In order to determine whether the increase in membrane FcyRIIB/RIII was due to impaired receptor endocytosis, we measured the rate of FcyRIIB/RIII internalization as described in Materials and Methods. We found similar Fc $\gamma R s$ internalization kinetics in both $\mathrm{M} \phi \mathrm{N}$ and $\mathrm{M} \phi \mathrm{P}$. Average decreases in MFI at $120 \mathrm{~min}$ were 14.82 and 15.79 units for $\mathrm{M} \phi \mathrm{N}$ and $\mathrm{M} \phi \mathrm{P}$, respectively, suggesting that FcyRIIB/RIII receptors endocytosis is not significantly altered by RSV persistence (Figure 4). 
Figure 4. Internalization of Fc $\gamma$ RIB/RIII in $\mathrm{M} \phi \mathrm{N}$ and $\mathrm{M} \phi \mathrm{P}$. Internalization kinetics of $\mathrm{mAb} 2.4 \mathrm{G} 2-\mathrm{Fc} \gamma \mathrm{RIIB} / \mathrm{RIII}$ complexes was monitored by flow cytometry during $120 \mathrm{~min}$, as described in Materials and Methods. Results are expressed as the mean \pm 1 SD from three independent experiments. No significant difference was observed between $\mathrm{M} \phi \mathrm{N}$ and $\mathrm{M} \phi \mathrm{P}$ in the net amount of internalized mAb 2.4G2-FcyRIIB/RIII complexes.

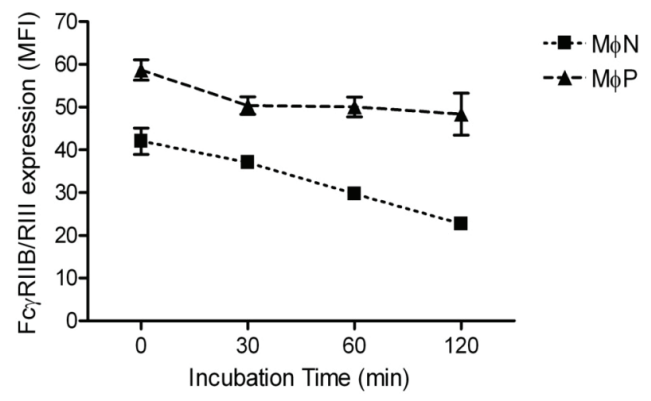

\subsubsection{Intracellular Levels of Fc $\gamma R$ IIB/RIII Proteins Are Increased in $\mathrm{M} \phi \mathrm{P}$}

In order to investigate whether the increase of Fc $\gamma$ RIIB/RIII expression on the membrane of M $\phi \mathrm{Ps}$ was associated with increased receptor synthesis, we determined the total amount of receptor protein (membrane and intracellular) in the cells using flow cytometry. We found out that $\mathrm{M} \phi \mathrm{Ps}$ have more

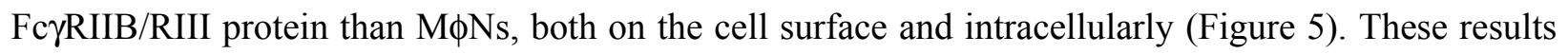
suggest that viral persistence induces the upregulation of Fc $\gamma$ RIIB/RIII synthesis.

Figure 5. Total FcyRIIB/RIII protein in $\mathrm{M} \phi \mathrm{N}$ and $\mathrm{M} \phi \mathrm{P}$. Cell-membrane and total FcyRIIB/RIII protein content were determined in non-permeabilized or permeabilized $\mathrm{M} \phi \mathrm{N}$ and $\mathrm{M} \phi \mathrm{P}$ cells. FcyRIIB/RIII expression was evaluated with $2.4 \mathrm{G} 2$ monoclonal antibody and analyzed by flow cytometry. Results are expressed as mean \pm 1 SD from three independent experiments, using different passages of $\mathrm{M} \phi \mathrm{N}$ and $\mathrm{M} \phi \mathrm{P}$.* indicates $p<0.05$.

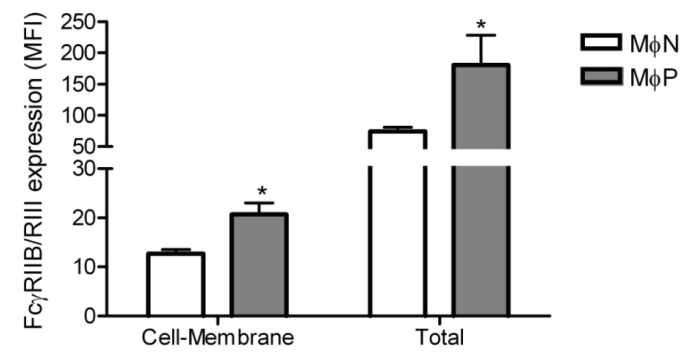

2.1.5. Membrane Expression of Fc $\gamma R$ RIB and FcyRIII, but Not of Fc $\gamma R I$, Is Increased in RSV Persistently Infected Cells

Four different types of murine Fc $\gamma$ receptors have been described (RI to RIV). In our initial work we

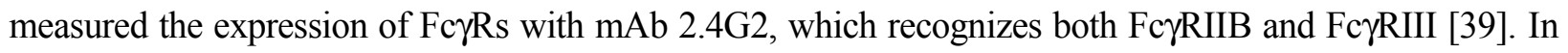

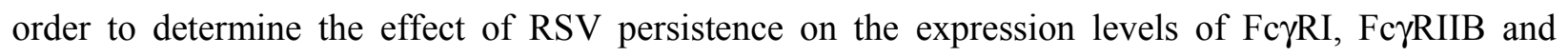

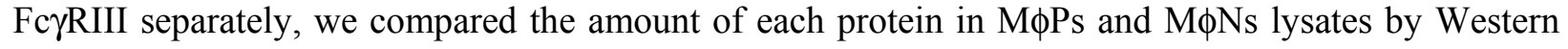
blot using antibodies specific for each isoform. Lack of a suitable commercial antibody prevented us from determining Fc $\gamma$ RIV. 


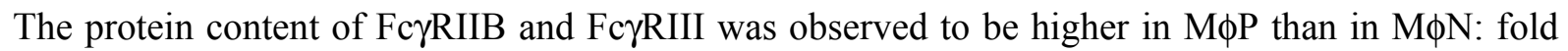
increases were 1.9 and 0.6 , respectively. In contrast, no significant difference was found in FcyRI levels between in $\mathrm{M} \phi \mathrm{P}$ and $\mathrm{M} \phi \mathrm{N}$ (Figure 6). It is interesting that the highest effect of RSV persistence

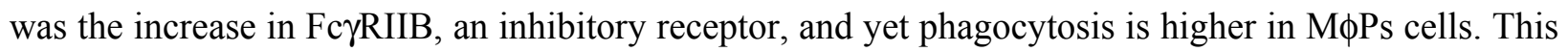
discrepancy might be related to the IgG isotype used for opsonization (IgG2b), which is very weakly recognized by FcyRIIB [40].

Figure 6. Total Fc $\gamma \mathrm{RI}, \mathrm{RIIB}$, and RIII protein in $\mathrm{M} \phi \mathrm{N}$ and $\mathrm{M} \phi \mathrm{P}$ cell extracts. (A) Cells from three different passages of $\mathrm{M} \phi \mathrm{N}$ and cells from passages 72, 83 and 87 of $\mathrm{M} \phi \mathrm{P}$ were

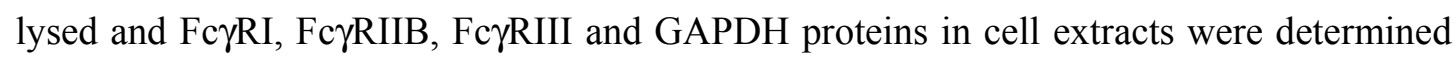
by Western blot with specific antibodies; (B) The relative amount of each Fc $\gamma \mathrm{R}$ isoform was determined as the ratio of the densitometric intensity of the Fc $\gamma \mathrm{R}$ band to the intensity of the GAPDH band in the correspondent cell extract. Results are expressed as mean \pm 1 $\mathrm{SD}(*$ indicates $p<0.05)$.
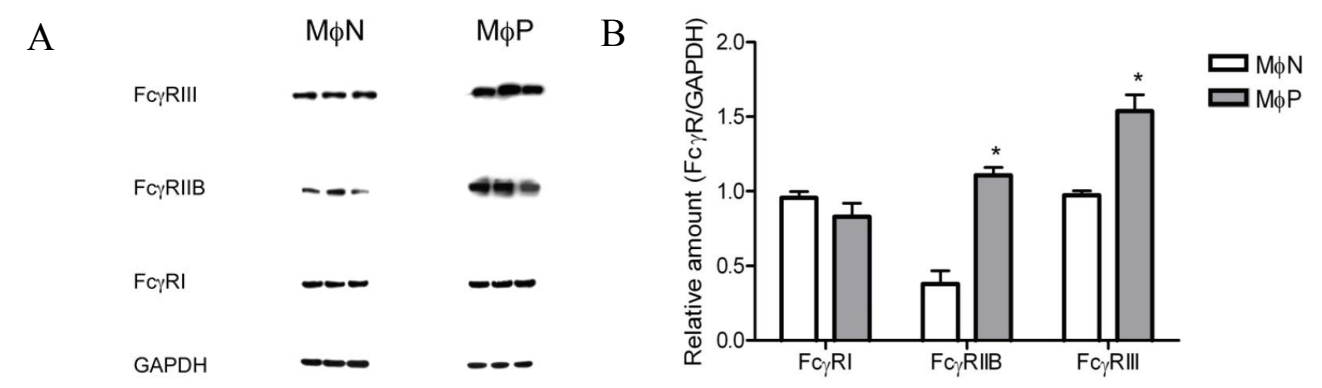

\subsection{6. mRNA Expression of FcyRs Is Distinctively Affected by Viral Persistence}

Since we could not evaluate the effect of RSV persistence on the expression of Fc $\gamma$ RIV by Western blot, and we wanted to have a better understanding of the effect of RSV persistence on the expression

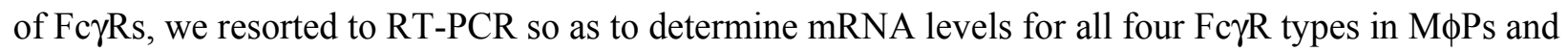

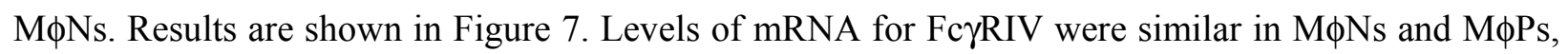
suggesting that RSV persistence has no effect in the expression levels of this receptor. As expected from the results of Western blots, mRNAs for FcyRIIB and Fc $\gamma R$ III were higher in M $\phi$ Ps than in $\mathrm{M} \phi N s$, with increases of 0.4 and 2.2 fold, respectively. Unexpectedly, we found that the Fc $\gamma R I$ mRNA was also increased ( 0.6 fold) in M $\phi$ Ps with respect to M $\phi N s$, which suggests that this receptor's expression level is also regulated at the post-transcriptional level.

\subsection{Discussion}

Viral persistence in cell lines is a well established model that can be used to study alterations in the expression profile of the host genome, which are caused by the constant expression of viral genes [1]. We and other researchers have shown that RSV persistence in cell cultures alters the profile of host genome expression. RSV persistence has been reported in various cell lines, and in two of them, HEp-2, (human epithelial cell line) [6] and P338D1 (murine macrophage-like cell line) [7], the characteristics resulting from persistent viral infection have been extensively studied. Although these two cell models of RSV persistence share several characteristics, they differ in some others. Thus, for instance, expression 
of viral antigens in RSV-infected HEp-2 cells ranges from nil to highly positive, a high titer of extracellular virus is produced, and syncytia are formed [6]. In contrast, we have found that the characteristics of viral persistence in an RSV-infected murine macrophage-like cell line, M $\phi \mathrm{P}$ (derived from P338D1), are different: $92 \%-96 \%$ of the cells express viral antigens - as determined by flow cytometry-low titers of extracellular infective virus are produced, and no syncytia are observed. These characteristics are still present after 87 passages. Also, RSV persistence produces an increase in the expression of Fc $\gamma R s$ and phagocytic activity in $\mathrm{M} \phi \mathrm{P}$ as compared to $\mathrm{M} \phi \mathrm{N}$. RSV persistence induced no cell activation, as evaluated by nitrite production. However, it is clear that RSV persistence induces alterations in the expression of host genes, as demonstrated by the downregulation of ICAM-1 [41] and upregulation of membrane receptors (FcyRs [8]), cytokines [8,42] and chemokines [43]. In addition, expression of the anti-apoptotic proteins Bcl-2, Bcl-X, and XIAP was enhanced, while Bcl-X and XIAP were regulated post-transcriptionally [44].

Figure 7. Fc $\gamma R$ s mRNA expression in $\mathrm{M} \phi \mathrm{N}$ and $\mathrm{M} \phi \mathrm{P}$. Total RNA from $\mathrm{M} \phi \mathrm{N}$ and $\mathrm{M} \phi \mathrm{P}$ cells was harvested and converted to cDNA, and mRNAs for Fc $\gamma$ RI, RIIB, RIII and RIV were measured by real-time PCR. Transcript levels were normalized to GAPDH mRNA expression. Data are expressed as $2^{-\Delta \mathrm{CT}}$. Results are shown as mean $\pm 1 \mathrm{SD}$ from three independent experiments using cells from passages 72,83 and 87 , * indicates $p<0.05$.

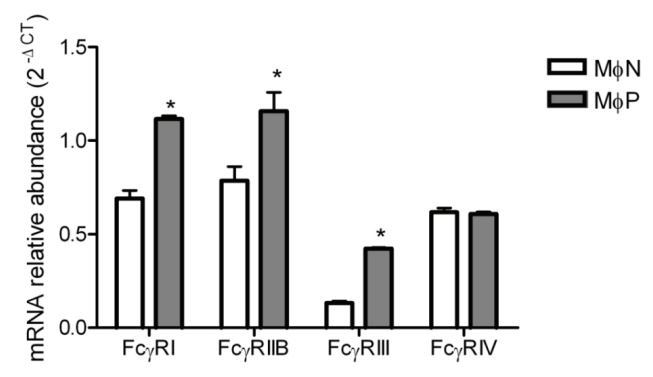

In this work, we focused on exploring the mechanisms possibly responsible for the increase in FcyR-mediated phagocytosis that we had previously reported to occur in early passages (14-40) of the persistently infected macrophage-like cell line $\mathrm{M} \phi \mathrm{P}$ [8]. This increase is still evident after 87 passages (Figure 2). The likelihood that the observed effect on Fc $\gamma R$ s expression resulted from an autocrine/paracrine-like action of factors (i.e., cytokines, viral particles, viral proteins) released by infected cells was ruled out, because extracellular components in conditioned medium from M $\phi \mathrm{P}$ did not alter FcyRIIB/RIII expression in $\mathrm{M} \phi \mathrm{N}$ (Figure 3). This suggests that the higher expression of FcyRIIB/RIII seen in M $\phi \mathrm{P}$ is not due to stimulation either by cytokines (IL-1 $\beta$, IL-6, [8]) or chemokines (RANTES, MIP-1 $\alpha$, MIP-1 $\beta$, MIP-2; Tirado R. personal communication), which have been detected in $\mathrm{M} \phi \mathrm{P}$ supernatants. We also analyzed the possibility that the observed increase in membrane expression of FcyRIIB/RIII resulted from a reduced rate of Fc $\gamma \mathrm{R}$ internalization induced by RSV persistence. However, we found no difference between $\mathrm{M} \phi \mathrm{N}$ and $\mathrm{M} \phi \mathrm{P}$ in the kinetics of Fc $\gamma \mathrm{RIIB} / \mathrm{RIII}$ internalization (Figure 4).

Since neither endocytic activity nor components of the conditioned medium (viral particles, viral proteins, cytokines, chemokines, etc.) seemed to participate in the increased FcyRs expression, we hypothesized that the observed effect of viral persistence was caused by RSV inducing an increase in 
the synthesis of FcyRs. Results obtained by flow cytometry assays of cell-membrane and intracellular protein expression (Figure 5) were consistent with our hypothesis. Since mouse cells express four different Fc $\gamma \mathrm{R}$ isoforms, and because up to this point we had only evaluated the expression of Fc $\gamma \mathrm{RIIB}$ and FcyRIII isoforms with a monoclonal antibody which recognizes both, we set out to determine the effect of RSV persistence in the expression of each of the four Fc $\gamma \mathrm{R}$ isoforms expressed by mouse

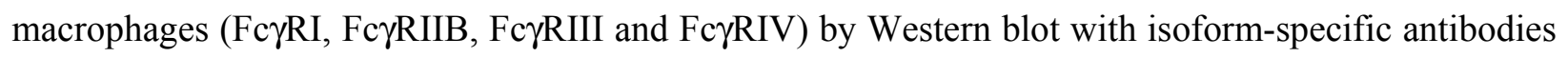
and by quantitative RT-PCR. We found out that RSV persistence distinctively affects expression of

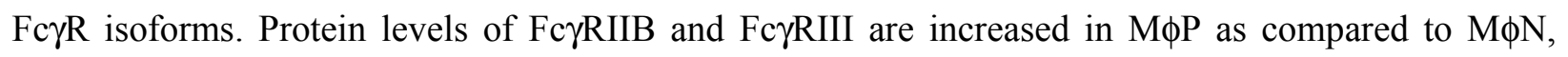

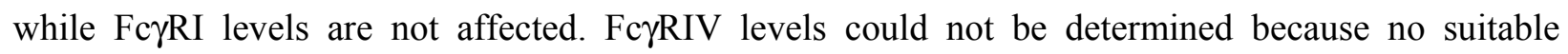
commercial antibody is available at present. However, since the levels of mRNA for Fc $\gamma R I V$ were not altered, it is reasonable to expect that the membrane expression of this isoform is not altered either.

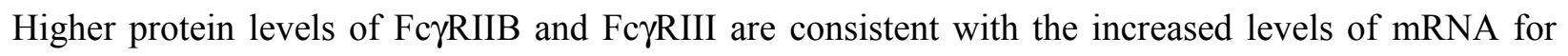
these two isoforms.

The effect of the observed changes in the expression of FcyR isoforms on the activation of effector functions of macrophages, is expected to depend on the IgG isotype involved [40]. IgG1 isotype has a

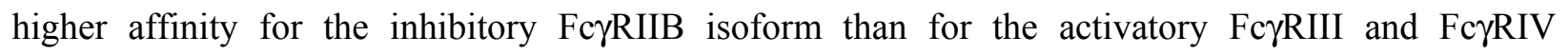
isoforms. Thus, the increases in FcyRIIB and FcyRIII expression would be expected to result in a lower cell response to immune complexes or opsonized particles containing IgG1. In contrast, IgG2a

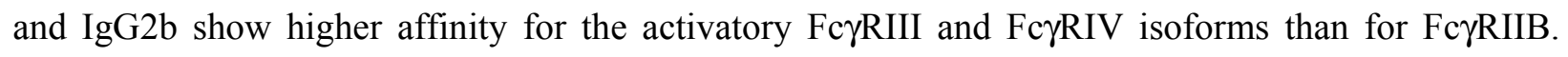
Therefore, effector functions mediated by these isotypes are less sensitive to changes in Fc $\gamma$ RIIB. In fact, this is consistent with our observation that FcyR-mediated phagocytosis of IgG2b-opsonized erythrocytes is increased in $\mathrm{M} \phi \mathrm{P}$. However, it should be kept in mind that phagocytosis is a complex cellular process, involving many proteins and signaling molecules - thus, it is not expected to depend solely on the expression of the receptor involved. For example, FcyRs-mediated phagocytosis in human monocyte-derived macrophages (MDM) increases after IL-10 treatment and decreases after IFN- $\gamma$ treatment, but these opposite effects do not correlate with the changes in Fc $\gamma \mathrm{R}$ expression induced by these cytokines [45]. The effect of RSV persistence on the expression of FcyRs mRNA suggests that RSV persistence is able to affect transcription factors, such as PU.1, which participates in FcyRs transcription [46]. Further work is underway in our laboratory in order to examine the participation of PU.1 in Fc $\gamma$ Rs transcription in RSV infected cells.

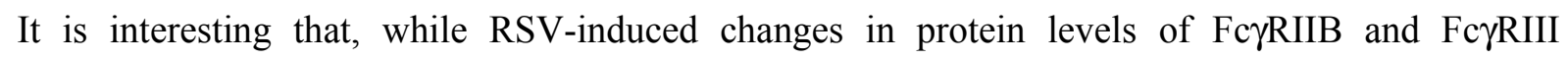
correlated with changes in the respective mRNA levels, Fc $\gamma \mathrm{RI}$ protein expression levels were not significantly affected by RSV persistence, although its mRNA was found to be increased. This suggests that expression of cellular genes in $\mathrm{M} \phi \mathrm{P}$ can be regulated at either the transcriptional and/or post-transcriptional levels. Consistent with this notion are studies reporting that the expression of transmembrane protein ICAM-1 is transcriptionally downregulated [41].

Changes in FcyRs expression in macrophages persistently infected with RSV, besides its effect on phagocytosis, could affect other effector functions mediated by these receptors, such as ADCC. However, as previously mentioned, effects of the observed changes are also expected to be highly influenced by the antibody isotypes involved. RSV persistence could also have an impact on the release of inflammatory mediators, thus affecting the functions of macrophages and other cells involved in host defense, although RSV persistence does not seem to alter endogenous or exogenous 
viral antigen presentation [42]. Additional studies are needed to further characterize the effects of RSV persistence in macrophages. Finally, it is important to study the effects of RSV persistence in human cells in order to evaluate the possible significance of these results to human disease, since differences have been reported in immune cells between mice and human [47].

\section{Experimental Section}

\subsection{Virus and Cell Lines}

The RSV Long strain wild type (wt RSV) has been the prototype virus used in our laboratory. Both the virus origin and the procedures for propagating, purifying and measuring its infectivity in Vero cells have been previously reported [7]. The murine macrophage-like cell line P388D1 was originally obtained from ATCC (TIB 63; Rockville, MD, USA). A sub-line of P388D1 cells persistently infected with wt RSV $(\mathrm{M} \phi \mathrm{P})$ was obtained in our laboratory by infecting the original cell line with RSV at a multiplicity of infection (moi) of 1 , and then culturing the surviving cells [7]. As control, P388D1 cells were mock-infected and subcultured in parallel conditions $(\mathrm{M} \phi \mathrm{N})$. Both cell lines are maintained by subculturing. M $\phi \mathrm{P}$ passages from 72 to 87 were used in this study. Throughout the passages, the presence of viral genome was monitored by detecting the mRNA of the gene $\mathrm{N}$ by conventional RT-PCR, using a primer pair to amplify a segment of 1,187 bp between nucleotides 1,140-2,327: forward 5'-ATGGCTCTTAGCAAAGTC-3', Reverse 5'-TTTTTTGTTAACTTCAAGCTCTACATC-3'. A segment of $260 \mathrm{bp}$ of GAPDH was amplified as control. RSV antigen was detected by flow cytometry on the surface of $92 \%-97 \%$ of the M $\phi \mathrm{P}$ using FITC-labeled polyclonal anti-RSV (Oxoid, Hampshire, UK), diluted 1:10 in PBS containing 0.1\% (w/v) BSA (PBSA) (Figure 1). Extracellular viral infectivity titer was $1-2 \times 10^{2} \mathrm{TCID}_{50} / \mathrm{mL}$ per $1-2 \times 10^{6}$ cells, and no syncytia were observed [7].

In order to verify lack of activation, the production of nitrates by $\mathrm{M} \phi \mathrm{N}$ and $\mathrm{M} \phi \mathrm{P}$ was routinely evaluated by the Griess reaction. Nitrate concentrations in supernatants usually ranged from: 7.1-8.0 $\mu \mathrm{mol} / \mathrm{mL}$ per $5-6 \times 10^{6}$ cells for $\mathrm{M} \phi \mathrm{N}$ and $8.3-10.2 \mu \mathrm{mol} / \mathrm{mL}$ per $5-6 \times 10^{6}$ cells for $\mathrm{M} \phi \mathrm{P}$.

Both cultures were propagated in RPMI 1640 medium (GIBCO/BRL, Grand Island, NY, USA) supplemented with $0.2 \% \mathrm{NaHCO}_{3}, 10 \mathrm{mM}$ HEPES, $1 \mu \mathrm{M}$ 2-mercaptoethanol, and $10 \%$ heat-inactivated $\left(56{ }^{\circ} \mathrm{C} ; 30 \mathrm{~min}\right)$ fetal bovine serum (FBS) (Biowest, Veracruz, Mexico).

\subsection{Phagocytosis Assays}

Phagocytosis of non-opsonized and IgG-opsonized sheep red blood cells (IgG-SRBC) was performed as previously described [8,48], but with minor modifications. In brief, SRBC were labeled with trinitrobenzene-sulfonic acid (TNBS, Sigma Aldrich Corp., St. Louis, MO, USA) $1 \mathrm{mg} / \mathrm{mL}$ for $30 \mathrm{~min}$ at room temperature. After washing, SRBCs were opsonized by incubation with one out of two different sub-hemagglutinating concentrations $(1.52$ or $2.28 \mu \mathrm{g} / \mathrm{mL})$ of affinity-purified murine monoclonal anti-DNP IgG (4F8; IgG2b, produced in our laboratory). Concentrations higher than $2.28 \mu \mathrm{g} / \mathrm{mL}$ could not be used due to agglutination of erythrocytes.

For phagocytosis assays, M $\phi \mathrm{N}$ or $\mathrm{M} \phi \mathrm{P}$ were plated in 96 -well plates $\left(1 \times 10^{5}\right.$ cells $/ 200 \mu \mathrm{L}$ of RPMI per well). Non-opsonized or opsonized SRBC ( $25 \mu \mathrm{L} /$ well of a $2 \%$ suspension of SRBC) were added, and the plates were incubated for $60 \mathrm{~min}$ at $37^{\circ} \mathrm{C}$. Non-ingested SRBC were lysed with distilled water, 
and the cells were exhaustively washed with PBS. Cells in the wells were lysed with sodium dodecyl sulfate (1\% in PBS), and the pseudoperoxidase activity of the ingested SRBC hemoglobin was determined by a colorimetric assay using 3,3'-diaminobenzidine as substrate. Optical density was read at $492 \mathrm{~nm}$. Results are expressed as phagocytic index $=$ (number of cells $\times$ Optical Density/100). In all experiments, phagocytosis of opsonized and non-opsonized SRBC was determined in sextuplicate wells. Controls for endogenous enzymatic activity consisted in lysates of six additional wells to which no SRBC had been added, treated under the same conditions.

\subsection{Flow Cytometry}

Cell surface expression of Fc $\gamma$ Rs was determined by flow cytometry using anti-Fc $\gamma$ RIIB/III (2.4G2, a rat monoclonal antibody that recognizes FcyRIIB and RIII epitopes) as unconjugated primary antibody and goat anti-rat F(ab') $)_{2}$-FITC as secondary antibody, both from Santa Cruz Biotechnology (Santa Cruz, CA, USA). Cells $\left(5 \times 10^{5}\right)$ from different $\mathrm{M} \phi \mathrm{P}$ or $\mathrm{M} \phi \mathrm{N}$ passages were washed with PBSA and fixed with $4 \%$ paraformaldehyde (30 min; room temperature). Fixed cells were washed with PBSA and incubated in PBS $+1 \%$ BSA containing $15 \mu \mathrm{g}$ of $2.4 \mathrm{G} 2$ antibody ( $2 \mathrm{~h}$; room temperature). After incubation, cells were washed twice with PBSA, and then incubated with goat anti-rat F(ab') $)_{2}$-FITC $(1 \mathrm{~h}$; at room temperature and protected from light). Cells were resuspended in PBS $(300 \mu \mathrm{L})$, and 10,000 cells were analyzed by flow cytometry (FACScan, Becton Dickinson, Mountain View, CA, USA). So as to determine intracellular proteins, cells were fixed and permeabilized with cold methanol:acetone, 1:1 (1 min; room temperature). Afterwards, cells were washed with PBSA and incubated in PBS $+1 \%$ BSA containing $10 \mu \mathrm{g}$ of $2.4 \mathrm{G} 2$ antibody ( $2 \mathrm{~h}$; room temperature). Following that incubation, cells were washed twice with PBSA and then incubated with goat anti-rat F(ab') $)_{2}$-FITC ( $1 \mathrm{~h}$; at room temperature and protected from light). Thereafter, cells were resuspended in $300 \mu \mathrm{L}$ of PBS and analyzed by flow cytometry.

\subsection{Conditioned Medium}

Confluent $\mathrm{M} \phi \mathrm{N}$ or $\mathrm{M} \phi \mathrm{P}$ cultures (approx. $5 \times 10^{6}$ cells) were washed with PBS, and then seven $\mathrm{mL}$ of supplemented RPMI were added. After 12 or $24 \mathrm{~h}$ of incubation at $37{ }^{\circ} \mathrm{C}$, supernatants were collected and cellular debris was removed by centrifugation $(352 \times g)$. (We know that cytokine concentrations in supernatants reach a plateau at $24 \mathrm{~h} \mathrm{[43]).} \mathrm{Two} \mathrm{mL}$ of this conditioned medium were added to $\mathrm{M} \phi \mathrm{N}$ cultures $\left(1 \times 10^{6}\right.$ cells $)$ and the cultures were incubated for $24 \mathrm{~h}$ at $37{ }^{\circ} \mathrm{C}, 5 \% \mathrm{CO}_{2}$ atmosphere. As positive stimulation control, $\mathrm{M} \phi \mathrm{N}$ were incubated with heat-killed non-typeable Haemophilus influenzae (NTHi) strain 2019 (moi of 100), kindly provided by Dr. Michael Apicella (Department of Microbiology, College of Medicine, University of Iowa, Iowa City, IA, USA). NTHi had been heat-killed ( $60 \mathrm{~min} ; 70{ }^{\circ} \mathrm{C}$ water bath), washed twice by centrifugation $(20 \mathrm{~min} ; 900 \times \mathrm{g}$; $4{ }^{\circ} \mathrm{C}$ ), and suspended in PBS at a final concentration of $1 \times 10^{10}$ bacteria/mL. The expression of Fc $\gamma$ RIIB/RIII was determined by flow cytometry, as described above. 


\subsection{Endocytosis Assay}

The endocytosis of cell-membrane FcyRIIB/RIII receptors was monitored with the monoclonal antibody 2.4G2. Briefly, 2.4G2 antibody was added to $\mathrm{M} \phi \mathrm{N}$ or $\mathrm{M} \phi \mathrm{P}\left(5 \times 10^{5}\right)$ cells at $20 \mu \mathrm{g} / \mathrm{mL}(30 \mathrm{~min}$, $4{ }^{\circ} \mathrm{C}$ ). After this period, cells were washed thoroughly with ice-cold medium without FBS. Endocytosis was started by adding medium at $37{ }^{\circ} \mathrm{C}$ and then incubating at $37^{\circ} \mathrm{C}$ for different periods of time $(0$, 30, 60, and $120 \mathrm{~min}$ ). Thereafter, cells were fixed with 4\% paraformaldehyde (30 min; room temperature) and washed. Afterwards, $\mathrm{F}\left(\mathrm{ab}^{\prime}\right)_{2}$-FITC against the primary antibody $2.4 \mathrm{G} 2$ was added. Fluorescence intensity was determined by flow cytometry as described above.

\subsection{Western Blot}

Whole-cell extracts were prepared from $\mathrm{M} \phi \mathrm{N}$ or $\mathrm{M} \phi \mathrm{P}\left(3 \times 10^{6}\right.$ cells $)$ with ice-cold lysing buffer (50 mM Tris- $\mathrm{HCl}, \mathrm{pH} 7.4,150 \mathrm{mM} \mathrm{NaCl}, 1 \%$ Triton $\mathrm{X}-100,0.5 \%$ sodium deoxycholate, and $0.1 \%$ SDS) containing $1 \times$ protease inhibitors cocktail (Sigma Aldrich Corp., St. Louis, MO, USA). After incubation (10 min on ice), lysates were collected and detergent-insoluble material was removed by centrifugation $\left(20 \mathrm{~min}, 4{ }^{\circ} \mathrm{C} ; 8,800 \times g\right.$ ). Protein concentration was determined using the DC protein assay kit (Bio-Rad, Hercules, CA, USA). Samples containing $20 \mu \mathrm{g}$ of protein each were then boiled in $4 \times$ SDS sample buffer and resolved on NovexBis-Tris Mini Gels NuPAGE (Invitrogen, Carlsbad, CA, USA). Subsequently, proteins were transferred to PVDF membranes (Amersham, Piscataway, NJ, USA) and nonspecific binding sites were blocked by immersing the membranes in blocking solution (PBS, 0.1\% Tween-20, and 5\% low-fat milk) (1 h, room temperature). After washing the membranes with PBS- $0.1 \%$ Tween-20, they were incubated with the primary antibody diluted 1:500 in blocking solution ( $4{ }^{\circ} \mathrm{C}$, overnight), followed by a peroxidase-conjugated appropriate secondary antibody (Santa Cruz Biotechnology, CA, USA), diluted 1:2,500 in blocking solution (1 h, room temperature). The

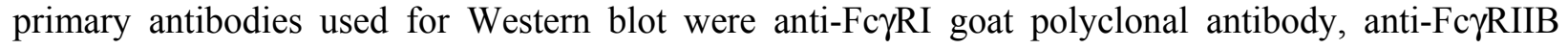
rabbit polyclonal antibody, anti-FcyRIII mouse monoclonal antibody (clone ASH1975), and anti-GAPDH, all from Santa Cruz Biotechnology. Proteins were detected using a chemiluminescent substrate, Super Signal West Dura Extended Duration substrate (Pierce Thermo Scientific, Rockford, IL, USA), and their intensities were normalized to that of GAPDH. Densitometric analysis of results was performed in images obtained with the Chemidox XRS (BioRad, Hercules, CA, USA) and analyzed with the Quantity one software (Bio-Rad).

\subsection{Real Time RT-PCR}

Total RNA was extracted from M $\phi \mathrm{N}$ or $\mathrm{M} \phi \mathrm{P}\left(2 \times 10^{6}\right.$ cells $)$ with TRIzol, following the manufacturer's instructions. RNA $(2 \mu \mathrm{g})$ was reverse transcribed with RNA transcriptase Superscript II (Invitrogen, Carlsbad, CA, USA). TaqMan real-time PCR was performed with primers and probes (assay on demand $20 \times$ mix) for Fc $\gamma$ Rs genes and GAPDH as control gene, using TaqMan assay reagent master mix (Applied Biosystems, Foster City, CA, USA). Real-time PCR was performed with $80 \mathrm{ng}$ of cDNA for both target genes and endogenous control. Cycling parameters were established according to the manufacturer's protocol. Triplicate CT values were analyzed in Microsoft Excel, using the comparative CT $(\Delta \mathrm{T})$ method as described by the manufacturer (Applied Biosystems, Branchburg, NJ, 
USA). The amount of mRNA from each target gene $\left(2^{-\Delta C T}\right)$ was obtained by normalizing it to the endogenous reference (GAPDH) sample.

\subsection{Statistics}

Data are expressed as mean \pm 1 SD from the indicated number of experiments. Differences between groups were determined by Student's $t$-test, using GraphPad Prism 4.0 software (GraphPad, San Diego CA, USA), and considered statistically significant at $p<0.05$.

\section{Conclusions}

RSV persistent infection in a murine macrophage-like cell line alters Fc $\gamma \mathrm{R}$ expression and induces

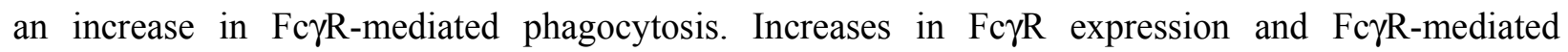
phagocytosis are preserved after more than 87 passages of the persistently infected culture. The increase in FcyRs expression results neither from soluble factors (cytokines) or viral products released by the infected cells, nor from an increase in the rate of Fc $\gamma \mathrm{R}$ internalization. Persistence of RSV genome in infected cells distinctly affects the expression of FcyR isoforms at both the mRNA and protein levels. These results indicate that RSV persistence, a phenomenon possibly more common than usually assumed, might affect the expression of cellular genes and, consequently, normal cell functions as well.

\section{Acknowledgments}

The authors thank Yvonne Rosenstein Azoulay, Carlos Rosales Ledezma and Evelyn Rivera-Toledo for helpful discussions and constructive comments during the course of this work, Olivia Reynoso Ducoing for technical assistance with Western blot assays, Rafael Palma for technical assistance with conditioned medium assays, Veronica Yakoleff for helpful comments, and Ma Pilar Ortega for English editing. The research was supported by grants from the Consejo Nacional de Ciencia y Tecnología (CONACYT), México (Grant 78862); Dirección General de Asuntos del Personal Académico, Universidad Nacional Autónoma de México (Grant PAPIIT IN23610-3); and Facultad de Medicina and PDCB, UNAM. Jorge Gaona was recipient of a scholarship from CONACYT (Scholarship 20313). This work is part of the PhD dissertation submitted by Jorge Gaona in partial fulfillment of the degree requirements.

\section{Author Contributions}

Beatriz Gómez, Enrique Ortega, and Jorge Gaona designed the experiments; Carlos Santiago-Olivares and Jorge Gaona performed the experiments; Beatriz Gómez, Enrique Ortega and Jorge Gaona prepared the manuscript. All authors read and approved the final manuscript.

\section{Conflicts of Interest}

The authors declare no conflict of interest. 


\section{References and Notes}

1. Oldstone, M.B. Anatomy of viral persistence. PLoS Pathog. 2009, 5, e1000523.

2. Anderson, C.F.; Gerber, J.S.; Mosser, D.M. Modulating macrophage function with IgG immune complexes. J. Endotoxin Res. 2002, 8, 477-481.

3. Biswas, S.K.; Chittezhath, M.; Shalova, I.N.; Lim, J.Y. Macrophage polarization and plasticity in health and disease. Immunol. Res. 2012, 53, 11-24.

4. Leeansyah, E.; Wines, B.D.; Crowe, S.M.; Jaworowski, A. The mechanism underlying defective Fcgamma receptor-mediated phagocytosis by HIV-1-infected human monocyte-derived macrophages. J. Immunol. 2007, 178, 1096-1104.

5. Kedzierska, K.; Azzam, R.; Ellery, P.; Mak, J.; Jaworowski, A.; Crowe, S.M. Defective phagocytosis by human monocyte/macrophages following HIV-1 infection: Underlying mechanisms and modulation by adjunctive cytokine therapy. J. Clin. Virol. 2003, 26, 247-263.

6. Martinez, I.; Lombardia, L.; Herranz, C.; Garcia-Barreno, B.; Dominguez, O.; Melero, J.A. Cultures of HEp-2 cells persistently infected by human respiratory syncytial virus differ in chemokine expression and resistance to apoptosis as compared to lytic infections of the same cell type. Virology 2009, 388, 31-41.

7. Sarmiento, R.E.; Tirado, R.; Gomez, B. Characteristics of a respiratory syncytial virus persistently infected macrophage-like culture. Virus Res. 2002, 84, 45-58.

8. Guerrero-Plata, A.; Ortega, E.; Gomez, B. Persistence of respiratory syncytial virus in macrophages alters phagocytosis and pro-inflammatory cytokine production. Viral Immunol. 2001, 14, 19-30.

9. Ravetch, J.V.; Bolland, S. IgG Fc receptors. Annu. Rev. Immunol. 2001, 19, 275-290.

10. Nimmerjahn, F.; Ravetch, J.V. Divergent immunoglobulin g subclass activity through selective Fc receptor binding. Science 2005, 310, 1510-1512.

11. Nimmerjahn, F.; Ravetch, J.V. Analyzing antibody-Fc-receptor interactions. Methods Mol. Biol. 2008, 415, 151-162.

12. Nimmerjahn, F.; Ravetch, J.V. Fcgamma receptors as regulators of immune responses. Nat. Rev. Immunol. 2008, 8, 34-47.

13. Nimmerjahn, F.; Ravetch, J.V. Antibody-mediated modulation of immune responses. Immunol. Rev. 2010, 236, 265-275.

14. Collins, P.L.; Melero, J.A. Progress in understanding and controlling respiratory syncytial virus: Still crazy after all these years. Virus Res. 2011, 162, 80-99.

15. Bont, L.; Houben, M.L. The epidemiology of respiratory syncytial virus lower respiratory tract infection on young children. Pediatr. Infect. Dis. J. 2012, 30, 778-784.

16. Van Drunen Littel-van den Hurk, S.; Watkiss, E.R. Pathogenesis of respiratory syncytial virus. Curr. Opin. Virol. 2012, 2, 300-305.

17. Habibi, M.S.; Openshaw, P.J. Benefit and harm from immunity to respiratory syncytial virus: Implications for treatment. Curr. Opin. Infect. Dis. 2012, 25, 687-694.

18. Walsh, E.E. Respiratory syncytial virus infection in adults. Semin. Respir. Crit. Care Med. 2011, 32, 423-432.

19. Welliver, R.C. Review of epidemiology and clinical risk factors for severe respiratory syncytial virus (RSV) infection. J. Pediatr. 2003, 143, S112-S117. 
20. Zeng, R.; Li, C.; Li, N.; Wei, L.; Cui, Y. The role of cytokines and chemokines in severe respiratory syncytial virus infection and subsequent asthma. Cytokine 2011, 53, 1-7.

21. Hall, C.B.; Douglas, R.G.; Geiman, J.M. Respiratory syncytial virus infections in infants: Quantitation and duration of shedding. J. Pediatr. 1976, 89, 11-15.

22. Szabo, S.M.; Levy, A.R.; Gooch, K.L.; Bradt, P.; Wijaya, H.; Mitchell, I. Elevated risk of asthma after hospitalization for respiratory syncytial virus infection in infancy. Paediatr. Respir. Rev. 2013, 13, S9-S15.

23. Piedimonte, G. Respiratory syncytial virus and asthma: Speed-dating or long-term relationship? Curr. Opin. Pediatr. 2013, 25, 344-349.

24. Openshaw, P.J.; Dean, G.S.; Culley, F.J. Links between respiratory syncytial virus bronchiolitis and childhood asthma: Clinical and research approaches. Pediatr. Infect. Dis. J. 2003, 22, S58-S64.

25. Sikkel, M.B.; Quint, J.K.; Mallia, P.; Wedzicha, J.A.; Johnston, S.L. Respiratory syncytial virus persistence in chronic obstructive pulmonary disease. Pediatr. Infect. Dis. J. 2008, 27, S63-S70.

26. Tripp, R.A. The brume surrounding respiratory syncytial virus persistence. Am. J. Respir. Crit. Care Med. 2004, 169, 778-779.

27. McNamara, P.S.; Smyth, R.L. The pathogenesis of respiratory syncytial virus disease in childhood. Br. Med. Bull. 2002, 61, 13-28.

28. Mejias, A.; Chavez-Bueno, S.; Gomez, A.M.; Somers, C.; Estripeaut, D.; Torres, J.P.; Jafri, H.S.; Ramilo, O. Respiratory syncytial virus persistence: Evidence in the mouse model. Pediatr. infect. Dis. J. 2008, 27, S60-S62.

29. Sutton, T.C.; Tayyari, F.; Khan, M.A.; Manson, H.E.; Hegele, R.G. T helper 1 background protects against airway hyperresponsiveness and inflammation in guinea pigs with persistent respiratory syncytial virus infection. Pediatr. Res. 2007, 61, 525-529.

30. Schwarze, J.; O’Donnell, D.R.; Rohwedder, A.; Openshaw, P.J. Latency and persistence of respiratory syncytial virus despite T cell immunity. Am. J. Respir. Crit. Care Med. 2004, 169, 801-805.

31. Bramley, A.M.; Vitalis, T.Z.; Wiggs, B.R.; Hegele, R.G. Effects of respiratory syncytial virus persistence on airway responsiveness and inflammation in guinea-pigs. Eur. Respir. J. 1999, 14, 1061-1067.

32. Hegele, R.G.; Hayashi, S.; Bramley, A.M.; Hogg, J.C. Persistence of respiratory syncytial virus genome and protein after acute bronchiolitis in guinea pigs. Chest 1994, 105, 1848-1854.

33. Riedel, F.; Oberdieck, B.; Streckert, H.J.; Philippou, S.; Krusat, T.; Marek, W. Persistence of airway hyperresponsiveness and viral antigen following respiratory syncytial virus bronchiolitis in young guinea-pigs. Eur. Respir. J. 1997, 10, 639-645.

34. Valarcher, J.F.; Bourhy, H.; Lavenu, A.; Bourges-Abella, N.; Roth, M.; Andreoletti, O.; Ave, P.; Schelcher, F. Persistent infection of b lymphocytes by bovine respiratory syncytial virus. Virology 2001, 291, 55-67.

35. Mills, B.G.; Frausto, A.; Singer, F.R.; Ohsaki, Y.; Demulder, A.; Roodman, G.D. Multinucleated cells formed in vitro from paget's bone marrow express viral antigens. Bone 1994, 15, 443-448.

36. Cubie, H.A.; Duncan, L.A.; Marshall, L.A.; Smith, N.M. Detection of respiratory syncytial virus nucleic acid in archival postmortem tissue from infants. Pediatr. Pathol. Lab. Med. 1997, 17, 927-938. 
37. Mohapatra, S.S.; Boyapalle, S. Epidemiologic, experimental, and clinical links between respiratory syncytial virus infection and asthma. Clin. Microbiol. Rev. 2008, 21, 495-504.

38. Herra, C.M.; Keane, C.T.; Whelan, A. Increased expression of Fc gamma receptors on neutrophils and monocytes may reflect ongoing bacterial infection. J. Med. Microbiol. 1996, 44, 135-140.

39. Unkeless, J.C. Characterization of a monoclonal antibody directed against mouse macrophage and lymphocyte fc receptors. J. Exp. Med. 1979, 150, 580-596.

40. Nimmerjahn, F.; Ravetch, J.V. Fcgamma receptors: Old friends and new family members. Immunity 2006, 24, 19-28.

41. Arrevillaga, G.; Gaona, J.; Sanchez, C.; Rosales, V.; Gomez, B. Respiratory syncytial virus persistence in macrophages downregulates intercellular adhesion molecule-1 expression and reduces adhesion of non-typeable haemophilus influenzae. Intervirology 2012, 55, 442-450

42. Guerrero-Plata, A.; Ortega, E.; Ortiz-Navarrete, V.; Gomez, B. Antigen presentation by a macrophage-like cell line persistently infected with respiratory syncytial virus. Virus Res. 2004, 99, 95-100.

43. Tirado, R.; Gómez, B. National Autonomous University of Mexico (UNAM), Ciudad Universitaria, D.F., México. Unpublished work, 2013.

44. Nakamura-Lopez, Y.; Villegas-Sepulveda, N.; Sarmiento-Silva, R.E.; Gomez, B. Intrinsic apoptotic pathway is subverted in mouse macrophages persistently infected by RSV. Virus Res. 2011, 158, 98-107.

45. Frausto-Del-Río, D.; Soto-Cruz, I.; Garay-Canales, C.; Ambriz, X.; Soldevila, G.; Carretero-Ortega, J.; Vázquez-Prado, J.; Ortega, E. Interferon gamma induces actin polymerization, rac1 activation and down regulates phagocytosis in human monocytic cells. Cytokine 2012, 57, 158-168.

46. Berclaz, P.Y.; Shibata, Y.; Whitsett, J.A.; Trapnell, B.C. GM-CSF, via PU.1, regulates alveolar macrophage Fcgamma R-mediated phagocytosis and the IL-18/IFN-gamma -mediated molecular connection between innate and adaptive immunity in the lung. Blood 2002, 100, 4193-4200.

47. Mestas, J.; Hughes, C.C. Of mice and not men: Differences between mouse and human immunology. J. Immunol. 2004, 172, 2731-2738.

48. Jungi, T.W. A rapid and sensitive method allowing photometric determination of erythrophagocytosis by mononuclear phagocytes. J. Immunol. Methods 1985, 82, 141-153.

(C) 2014 by the authors; licensee MDPI, Basel, Switzerland. This article is an open access article distributed under the terms and conditions of the Creative Commons Attribution license (http://creativecommons.org/licenses/by/3.0/). 